\title{
Toward Firm Performance in Indonesia: The Role of Good Corporate Governance and Investment Opportunity Set
}

\author{
Dedi Rusdi $^{1}$, Indri Kartika ${ }^{2}$, Maya Indriastuti ${ }^{3^{*}}$ \\ ${ }^{1,2,3}$ Department of Accounting, Faculty of Economics, Universitas Islam Sultan Agung, Indonesia \\ dedirusdi@unissula.ac.id,indri@unissula.ac.id,maya@unissula.ac.id*correspondingauthors
}

\begin{abstract}
This study examined the role of good corporate governance and investment opportunity set in maintaining firm performance. This study's sample population comprised 240 manufacturing companies listed on the Indonesia Stock Exchange from 2016 to 2019. The research sample was selected using a purposive sampling method. The data were analyzed by using structural equation modeling analysis (SEM). The results showed that good corporate governance in terms of board size had a negative effect on firm performance. Meanwhile, good corporate governance in terms of board independence and investment opportunity set had a positive effect on firm performance.
\end{abstract}

Keywords: good corporate governance, investment opportunity set, firm performance

\section{Menuju Kinerja Perusahaan di Indonesia: Peran Good Corporate Governance dan Investment Opportunity Set}

\begin{abstract}
Abstrak
Studi ini menguji peran good corporate governance dan investment opportunity set dalam menjaga kinerja perusahaan. Populasi sampel penelitian terdiri dari 240 perusahaan manufaktur yang terdaftar di Bursa Efek Indonesia dari tahun 2016 hingga 2019. Sampel penelitian dipilih dengan menggunakan metode purposive sampling. Analisis data menggunakan analisis structural equation modeling (SEM). Hasil penelitian menunjukkan bahwa good corporate governance ditinjau dari ukuran dewan komisaris berpengaruh negatif terhadap kinerja perusahaan. Sedangkan good corporate governance ditinjau dari independensi dewan komisaris dan investment opportunity set berpengaruh positif terhadap kinerja perusahaan.
\end{abstract}

Kata kunci: good corporate governance, investment opportunity set, kinerja perusahaan

\section{INTRODUCTION}

Firm performance is the depiction of a company's financial condition (Park et al., 2017). Firm performance helps to find out the pros and cons of finance in a certain period. It also describes the company's work performance. The firm performance is reflected through the closing stock prices of manufacturing companies on the Indonesia Stock Exchange. The CSPI (Composite Stock Price Index) in 2017-2018 reached an average of 1,566,312. However, in June 2020, the CSPI had dropped significantly by 1,204,767 (www.idx.co.id). Therefore, to improve firm performance, good corporate governance and investment opportunity set are needed. Corporate governance is an essential factor for the company's survival. It can eliminate various frauds such as collusion, corruption, and nepotism in companies. Furthermore, it also creates a healthy business and builds the trust of investors and creditors (Nurlis, 2016). In the current era, good corporate governance in this study includes board size and board independence. 
Board size plays an essential role in determining the level of effectiveness. A large number of company's members can worsen the firm performance (Danquah et al., 2018). According to Yilmaz \& Buyuklu (2016), board size has a negative effect on firm performance. It is because a large number of board members can slow down the process of decision making. Appiadjei et al., (2017); Danquah et al., (2018); Mohan and Chandramohan (2018) also stated that board size has a negative effect on firm performance. On the other hand, Buallay et al., (2017); Rehman \& Shah (2013) found that many board members can improve the board's ability and expertise. Therefore board size has a positive effect on firm performance.

The company's independent board can be the mediator for internal managers just if there is a dispute. Independent board also can supervise policies and advise directors. The greater independence of the board in the company will create a good and healthy firm performance. As a result, it can minimize fraud. Rehman \& Shah (2013) proposed that the independent board has a positive and significant effect on firm performance. This is consistent with the findings of Danquah et al., (2018); Gordini (2012). They explained that there is a significant positive relationship between the independent board and firm performance. In contrast, Mollah et al., (2012) argued that an Independent board has a negative effect on firm performance through ROA (Return on Asset). It explains that the higher independence of the board can decrease the company's ROA. Additionally, the company has a low ability in generating profit. Jerry et al., (2014); Yilmaz \& Buyuklu (2016) indicated that independent board has a negative effect on firm performance.

Besides good governance, the firm performance is also influenced by the investment opportunity set variable. Jerry et al., (2014) found that it must utilize its investment opportunity set to see its market potential. Companies with a high investment opportunity set will result in investors' positive signals to attract the investors' interest. A significant return in the future also becomes the goal. Christiningrum (2015) explained that investment opportunity set has a positive effect on firm performance.

Based on the explanation above, this study aims to analyze the effect of good corporate governance and investment opportunity set on firm performance. Since the firm performance is a depiction of the company's work performance, the company will maintain the outstanding stock price in the stock market. This study's results are expected to be used as a reference and can provide insight for making a company's policies.

\section{Board Size and Firm Performance}

Good corporate governance implementation in the company can overcome agency problems between managers and shareholders. It is due to the separation between control and management. In this case, the functions of management and ownership are separated by different parties (Jensen \& Mecking, 1976). The separation is in the form of a board of directors and a board of commissioners who are fully responsible for the company's operations according to the company's interests and objectives. The board of directors and the board of commissioners are essential. They can bridge the interests of the principals in companies that have the primary function to supervise the completeness and quality of 
report information (Danquah et al., 2018). The board size of directors and commissioners relatively small and proportionate to the company can result in management control and carry out their duties effectively. Conversely, if the number of boards of directors and commissioners is too big, it will result in a slow pace in decision-making, which ultimately leads to a decline in firm performance. This statement is supported by Appiadjei et al., (2017); Danquah et al., (2018); Mohan and Chandramohan (2018); Yilmaz \& Buyuklu (2016) that board size has a negative effect on firm performance.

$H_{1:}$ Good corporate governance in term of board size has a negative effect on firm performance.

\section{Board Independence and Firm Performance}

A manager in managing a company often prioritizes his interests and continuously ignores the shareholders' interests. Therefore the manager spreads asymmetric information that is not in line with the actual condition of the company. Asymmetric information occurs because of the manager's opportunistic behavior. Thus it needs an independent board to supervise and control the behavior of the management (Jensen \& Mecking, 1976). An Independent board consists of a member who has no relationship with the management and family of the board of commissioners or board of directors. They also have no financial relations or share ownership (Danquah et al., 2018). Rehman \& Shah (2013) added that an independent board could also act as an intermediary if there is a dispute among internal managers. Independent board can advise directors on their decisions. The independent board is expected to be able to have a positive impact on firm performance. These findings are in line with Danquah et al., (2018); Gordini (2012). They indicated that board independence has a positive and significant effect on firm performance.

$H_{2:}$ Good corporate governance in term of independent board has a positive effect on firm performance

\section{Investment Opportunity Set on Firm Performance}

The investment opportunity set is the present value that aims to make future investments become the company's option. Market value has an important component, namely investment opportunity. It is because the level of investment opportunity influences the perspective of managers, owners, investors, and creditors (Jerry et al., 2014). Investment opportunity affects the stock market value, which becomes the indicator of the company's growth. The company's growth in the future can give a positive signal as a form of investment expenditure. Investment option can be used as an opportunity for a company to develop. Christiningrum (2015) also found that investment opportunity set has a positive effect on firm performance.

$H_{3}$ : Investment opportunity set has a positive effect on firm performance 


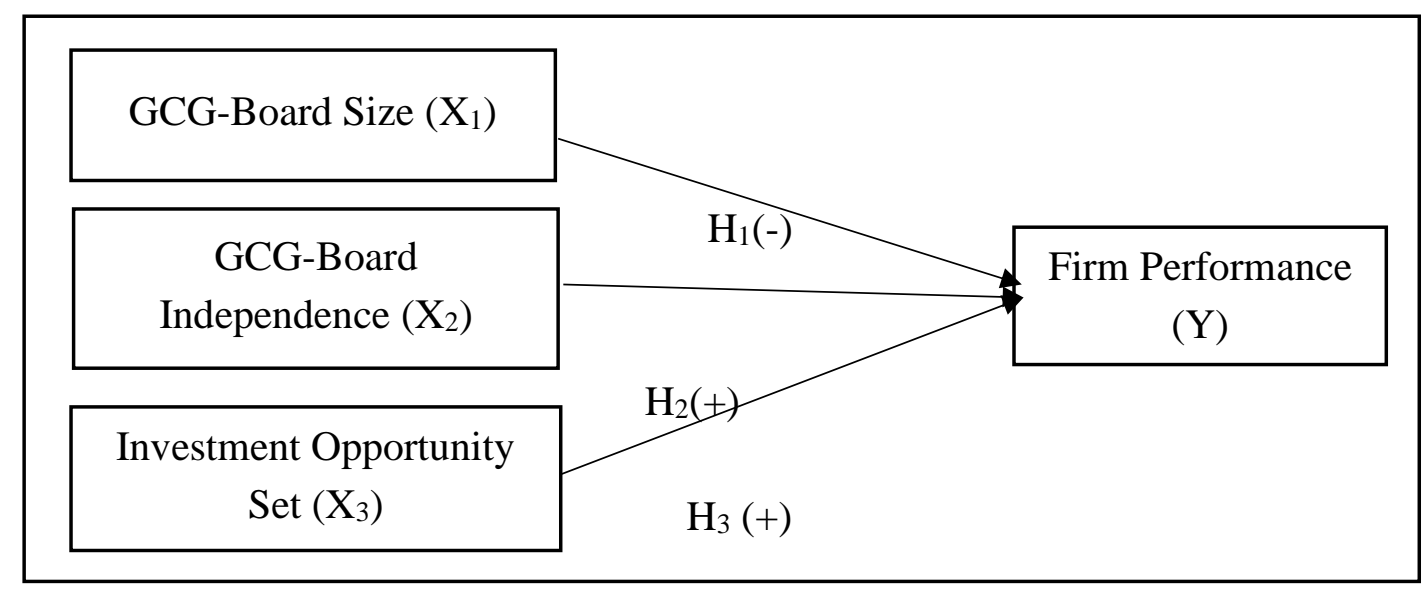

Figure 1. Research Model

\section{METHOD}

This section describes research planning and design. This section should describe the type of research, research's subject and object, research instrument, and data analysis method. The sample population in this comprised all companies listed on the Indonesia Stock Exchange from 2016 to 2019 that can be accessed at www.idx.co.id. The sample in this study was selected using the purposive sampling method with the following criteria:

1. Manufacturing companies listed on Indonesia Stock Exchange from 2016-2019.

2. Manufacturing companies that publish annual reports for the period of December 31 , 2016-2019.

3. Manufacturing companies presented complete data related to the research variables.

4. Manufacturing companies that present annual reports in the rupiah currency.

Thus the final sample comprised 240 manufacturing companies (60 manufacturing companies $\mathrm{x} 4$ years).

Firm performance was measured by using Price Earning Ratio (PER) proxy. Price Earning Ratio (PER) is the ratio between stock price and earning per share. Price Earning Ratio (PER) can reflect accurate information on investment activities to generate a profit. Thus it helps investors assess the achievement of firm performance both in the present and in the future (Kasmir, 2015). Board size is measured by adding up all members of the board both the board of directors and the board of commissioners in the company (Danquah et al., 2018). Board independence is measured by adding up all members of the board of commissioners who are not coming from affiliated parties known as commissioners in the company (Danquah et al., 2018). Investment opportunity set can be measured using Market Value Equity to Book Value Equity (MVE / BVE) proxy. It is under a condition where the company's return on future investment will be greater than the expected return on equity (Jerry et al., 2014). This study's data analysis technique is SEM-PLS (Structural Equation Modeling based on Partial Least Square) with SmartPLS 3.0 application. SmartPLS 3.0 is designed to analyze latent variables by using manifest variables, multiple regression models, and path analysis through observed variables (Ghozali \& Latan, 2015). 
Information:

$$
\eta 1=\gamma 1 \xi 1+\gamma 2 \xi 2+\gamma 3 \xi 3+\varsigma 1
$$
$\eta 1$
: Firm Performance
$\gamma 1, \gamma 2, \gamma 3$ : Coefficient
$\xi 1 \quad$ : Good Corporate Governance in term of Board Size
छ2 $\quad$ : Good Corporate Governance in term of Board Independence
$\varsigma \quad$ : Residual Value

\section{FINDING AND DISCUSSION}

Descriptive Statistic Analysis

Table 1. Descriptive Statistic

\begin{tabular}{lcccccc}
\hline \multicolumn{1}{c}{ Variable } & $\mathrm{N}$ & Min & Max & Mean & Median & $\begin{array}{c}\text { Standard } \\
\text { Deviation }\end{array}$ \\
\hline Board Size & & 4.000 & 21.000 & 9.383 & 8.000 & 3.956 \\
Board Independence & & 0.000 & 5.000 & 2.325 & 2.000 & 1.042 \\
Investment Opportunity & 240 & -1.220 & 31.195 & 2.620 & 1.102 & 4.848 \\
Set & & -47.826 & 86.767 & 15.295 & 13.615 & 18.444 \\
Firm Performance & & & & & & \\
\hline
\end{tabular}

Table 1 shows that board size has a minimum value of 4,000 with a maximum value of 21,000, a mean value of 8,000 , an average value of 9,383, and a standard deviation of 3.956. The minimum value was in Kertas Basuki Rachmat Indonesia company in 20162019. Meanwhile, the maximum value was in Mandom Indonesia company (TCID) in 2016-2019. Board independence has a minimum value of 0.000 with a maximum value of 5,000 , the mean value of this 2,000 , the average value of 2.325 , and the standard deviation, which shows the research variable is 1.042 . The minimum value occurred in Ekadharma International company (EKAD) in 2016, whereas the maximum value occurred in Astra International company (ASII) in 2019. The investment opportunity set variable had a minimum value of 1,220 in Primarindo Asia Infrastructure Tbk (BIMA) in 2018. Meanwhile, the maximum value of 31,195 occurred in Nippon Indosari Corpindo company (ROTI) in 2018, with a median value of 1,102 , an average value of 2,620 , and a standard deviation of 4,848 . The firm performance variable with a minimum value of $-47,826$ was in Prima Alloy Steel Universal company (PRAS) in 2018. The maximum value of 86,767 occurred in the Sekar Bumi company (SKBM) in 2019, with the mean value of this variable is 13,615 , the average value is 15.295 , and the standard deviation is 18.444 .

Table 2 shows the value of outer loadings generated more than 0.70 . Thus, each variable has an excellent convergent validity value, and the convergent validity requirements have been fulfilled. Meanwhile, the results of the average variance extracted output indicate that the AVE value is good for each construct because it has a value greater than 0.50 , and it fulfilled the requirements. 
The Result of Measurement Model (Outer Model)

Convergent Validity and Average Variance Extracted (AVE)

Table 2. Outer loadings and Average Variance Extracted (AVE)

\begin{tabular}{ccccc}
\hline & $\begin{array}{c}\text { Board } \\
\text { Size }\end{array}$ & $\begin{array}{c}\text { Board } \\
\text { Independence }\end{array}$ & $\begin{array}{c}\text { Investment } \\
\text { Opportunity Set }\end{array}$ & $\begin{array}{c}\text { Firm } \\
\text { performance }\end{array}$ \\
\hline BS & 1.000 & & & \\
\hline BI & & 1.000 & & \\
\hline MVE/BVE & & & 1.000 & 1.000 \\
\hline PER & & & 1.000 & 1.000 \\
\hline AVE & 1.000 & 1.000 & & \\
\hline
\end{tabular}

Discriminant Validity and Composite Reliability

Table 3. Cross loadings, Composite Reliability and Cronbach Alpha

\begin{tabular}{ccccc}
\hline & $\begin{array}{c}\text { Board } \\
\text { Size }\end{array}$ & $\begin{array}{c}\text { Board } \\
\text { Independence }\end{array}$ & $\begin{array}{c}\text { Investment } \\
\text { Opportunity Set }\end{array}$ & $\begin{array}{c}\text { Firm } \\
\text { performance }\end{array}$ \\
\hline BS & 1.000 & -0.897 & -0.516 & -0.872 \\
\hline BI & -0.897 & 1.000 & 0.664 & 0.906 \\
\hline MVE/BVE & -0.516 & 0.664 & 1.000 & 0.812 \\
\hline PER & -0.872 & 0.906 & 0.812 & 1.000 \\
\hline Cronbach's Alpha & 1.000 & 1.000 & 1.000 & 1.000 \\
\hline $\begin{array}{c}\text { Composite } \\
\text { Reliability }\end{array}$ & 1.000 & 1.000 & 1.000 & 1.000 \\
\hline
\end{tabular}

Table 3 shows that each construct with its indicator has a higher cross-loading value than the other constructs. It means that the latent constructs can be predicted better by each indicator than indicators from other constructs. The composite reliability value results and Cronbach's alpha are more than 0.70 , equal to 1,000 . It means that each latent construct has good reliability because it fulfilled the requirements of the composite reliability test and Cronbach's alpha.

Structural Model Test Result (Inner Model)

Determinant Coefficient $\left(R^{2}\right)$

Table 4. R-Square $\left(\mathrm{R}^{2}\right)$

\begin{tabular}{ccc}
\hline & R-Square & R Square Adjusted \\
\hline Firm performance & 0,619 & 0,747 \\
\hline
\end{tabular}

Table 4 shows that the R-Square Adjusted value on the firm performance variable is 0.747 or $74.7 \%$. In other words, the firm performance variable can be explained by the board size, board independence, and investment opportunity set variables of $74.7 \%$. Meanwhile, the remaining $25.3 \%$ are defined by other variables.

Hypothesis Result (T-Test)

The board size column shows the original sample for -0.583 . The p-value is 0,000 ; it is following the requirement of $\mathrm{p}$ values $<0.050$. Meanwhile, in the T-statistic column 7,650, 
it can be valid under the T-statistic value requirements $>1.96$. So the first hypothesis (H1) is accepted. It means that board size has a negative and significant effect on accepted firm performance. Board independence on firm performance has a parameter coefficient of 0.165 found in the original sample column. The result of $p$-value is 0,000 and the value of $t$ statistics is 5,030 where the results fulfill the requirements ( $p$-value $<0.050$ and $t$-statistics value>1.96). Thus the second hypothesis (H2) is accepted. It means that board independence has a positive and significant effect on firm performance. The investment opportunity set for the parameter coefficient is 0.409 in the original sample column. $P$ values indicate a value of 0,000 , which is smaller than 0.050 , so it belongs to significant and fulfills the requirements. Meanwhile, the t-statistic value of 7.882 is said to be valid because the results fulfill the requirements of the t-statistic value $>1.96$. Therefore the third hypothesis (H3) is accepted. In other words, the investment opportunity set has a positive and significant impact on firm performance.

Table 5. Path Coefficients

\begin{tabular}{lcccccc}
\hline & $\begin{array}{c}\text { Original } \\
\text { Sample } \\
(\mathrm{O})\end{array}$ & $\begin{array}{c}\text { Sample } \\
\text { Mean } \\
(\mathrm{M})\end{array}$ & $\begin{array}{c}\text { Standard } \\
\text { Deviation } \\
(\text { STDEV })\end{array}$ & $\begin{array}{c}\text { T Statistics } \\
(\mid \mathrm{O} / \text { STDEV } \mid)\end{array}$ & $\begin{array}{c}\text { P- } \\
\text { Values }\end{array}$ & Decision \\
\hline $\begin{array}{l}\text { Board Size } \\
\text { Firm }\end{array}$ & $\mathbf{- 0 . 5 8 3}$ & -0.582 & 0.076 & 7.650 & 0.000 & $\begin{array}{c}\text { H1 } \\
\text { Accepted }\end{array}$ \\
$\begin{array}{l}\text { Performance } \\
\text { Board }\end{array}$ & & & & & 0.000 & H2 \\
$\begin{array}{l}\text { Independence } \\
\begin{array}{l}\text { Firm } \\
\text { Performance }\end{array}\end{array}$ & $\mathbf{0 . 1 6 5}$ & 0.160 & 0.033 & 5.030 & & Acced \\
$\begin{array}{l}\text { IOS } \rightarrow \\
\begin{array}{l}\text { Firm } \\
\text { Performance }\end{array}\end{array}$ & $\mathbf{0 . 4 0 9}$ & 0.406 & 0.052 & 7.882 & 0.000 & Accepted \\
\hline
\end{tabular}

\section{Board Size and Firm Performance}

Good corporate governance in terms of board size has a negative effect on firm performance. A large number of board members can slow down decision-making, which also leads to an irrelevant decision. It also can cause the decline of firm performance, and the company cannot maximize its ability to take the business opportunities. The board size can reduce agency conflicts between agents and principals. According to the General Guidelines of Good Corporate Governance in Indonesia, the number of board of directors and board of commissioners must be adjusted to the company's complexity and pay attention to the decision-making effectiveness. (Danquah, et al., 2018) also emphasized that the larger the board member's size controls, the less effective company management and performance. This statement is supported by Appiadjei et al., (2017); Mohan and Chandramohan, (2018); Yilmaz \& Buyuklu (2016). They agreed that board size has a negative effect on firm performance. On the contrary, Buallay et al., (2017); El-Chaarani (2014); Rehman \& Shah (2013) found that board size can increase the variety of expertise and information in the company; thus it has a positive effect on firm performance. 


\section{Board Independence and Firm Performance}

Good corporate governance in terms of the independent board has a positive and significant effect on firm performance. In other words, the more independent a board of commissioners can result in better firm performance. It is because there is a balance between supervision and control within the company. Salami (2011) suggested that implementing corporate governance in terms of an independent board will be an obstacle for managers to make decisions and policies following personal interests. This implementation also can create transparency, accountability, responsibility, independence, and fairness. Independent board can control and supervise management behavior. It also motivates the managers to carry out tasks under company interests to minimize agency conflict. Independent board is also capable of protecting company stakeholders, reducing agency costs, and making decisions objectively according to company goals without prioritizing personal interests. Danquah et al., (2018); Gordini (2012); Rehman \& Shah (2013) found that there is a positive and significant relationship between the independent board and firm performance. However, Yilmaz \& Buyuklu (2016) rgued that an independent board could not guarantee that the firm performance will improve. It is because it cannot hinder managers' behavior in maximizing their interests so that the company's targets are challenging to achieve. Mollah et al., (2012); Jerry et al., (2014) supported this statement that an independent board has a negative effect on firm performance.

\section{Investment Opportunity Set on Firm Performance}

Investment opportunity set has a positive and significant effect on firm performance. It means that manufacturing companies can manage additional share capital to increase productive assets so that firm performance will improve. The investment opportunity set can also increase high market value so that investors will respond positively by investing their shares. It is because the company can provide a good return through high stock prices. The company's investment opportunity can also increase investment opportunities that can mitigate agency conflicts in the company. It is because an investment opportunity set can give benefits for both parties between managers and shareholders. However, a high investment opportunity set requires more funds to finance capital and find funding sources in the capital market. A good firm performance must support efforts to get funds from the capital market. These findings are consistent with Christiningrum (2015); Obeten et al., (2014). They found that investment opportunity set has a positive effect on firm performance. However, it is in contrast with the research of Jerry et al., (2014). They indicated that investment opportunity set has a negative effect on firm performance.

\section{CONCLUSION}

This study examined the role of good corporate governance and investment opportunity set in maintaining firm performance. The main finding was good corporate governance in terms of board size negatively affected the firm performance. Meanwhile, good corporate governance in terms of board independence and investment opportunity set positively affected the firm performance. The implication of the research results is; first, this research 
can be used as a reference. Second, this research can guide policymakers, such as government and manufacturing companies. This research's limitation lies in the differences between the number of financial statements and the number in the annual report. Further research can use the latest annual report data taken from the website of the company or Indonesia stock exchange so that the results will be more valid and consistent.

\section{REFERENCES}

Appiadjei, E. A., Ampong, G. O., \& Nsiah, F. (2017) 'Board, Gender Diversity and Firm Performance', International Journal of Economics, Commerce and Management, 5(10), pp. $1-16$. Available

at: https://www.researchgate.net/publication/320597742_BOARD_GENDER_DIVE RSITY_AND_FIRM_PERFORMANCE.

Buallay, A., Hamdan, A., \& Zureigat, Q. (2017) 'Corporate Governance and Firm Performance: Evidence from Saudi Arabia', Australasian Accounting, Business and Finance Journal, 11(1), pp. 79-98. Available at: doi: http://dx.doi.org/10.14453/aabfj.v11i1.6\%0A\%0A.

Christiningrum MF (2015) 'Effect of Diversification Strategy, Leverage and IOS on Multi Segment Corporate Performance In Indonesia.', Mediterranean Journal of Social Sciences, 6(55), pp. 157-166. Available at: doi: 10.5901/mjss.2015.v6n5s5p157.

Danquah, B. S., Gyimah, P., Afriyie, R. O., \& Asiamah, A. (2018) 'Corporate Governance and Firm Performance: An Empirical Analysis of Manufacturing Listed Firms in Ghana.', Accounting and Finance Research, 7(3), pp. 111-118. Available at: doi: https://doi.org/10.5430/afr.v7n3p11.

El-Chaarani, H. (2014) 'The Impact of Corporate Governance on The Performance of Lebanese Banks.', The International Journal of Business and Finance Research, 8(5), pp. $35-46$.

Available

at: https://www.researchgate.net/publication/327465484_The_impact_of_corporate_g overnance_on_the_performance_of_Lebanese_banks/link/5b90a194299bf114b7fce 4 7e/download.

Ghozali, I. and H. L. (2015) Concepts, Techniques, Applications Using Smart PLS 3.0 for Empirical Research. Semarang: Diponegoro University Publisher.

Gordini, N. (2012) 'The Impact of Outsiders on Small Family Firm Performance: Evidence from Italy', World Journal of Management, 4(2), pp. 14-35. Available at: https://ssrn.com/abstract=2215626.

Jensen, M. C., \& Meckling, W. H. (1976) 'Theory of the Firm: Managerial Behaviour, Agency Costs and Ownership Structure', Journal of Financial Economics, 3, p. 305360. Available at: https://doi.org/10.1016/0304-405X(76)90026-X.

Jerry Sun \& George Lan \& Zhenzhong Ma (2014) 'Investment Opportunity Set, Board Independence, and Firm Performance.', Managerial Finance, 4(5), pp. 454-468. Available at: doi:10.1108/mf-05-2013-0123 .

Kasmir (2015) Analisis Laporan Keuangan. Jakarta: Rajawali Pers. 
Mohan, Aswathy and Chandramohan, S. (2018) 'Impact of Corporate Governance on Firm Performance: Empirical Evidence from India', IMPACT: International Journal of Research in Humanities, Arts and Literature (IMPACT: IJRHAL), 6(2), pp. 209-218. Available at: ssrn: https://ssrn.com/abstract=3133491.

Mollah, S., Karim, W., \& Farooque, Q. A. (2012) 'Ownership Structure, Corporate Governance and Firm Performance Evidence from an African Emerging Market.', Studies in Economics and Finance, 29(4), pp. 301-319. Available at: doi:10.1108/10867371211266937.

Nurlis. (2016) 'The Effect of Mechanism of Good Corporate Governance and Investment Opportunity Set on The Earning Management: Study on Property And Real Estate Companies Are Listed In Indonesia Stock Exchange', Europen Journal of Business and Management, 8(2), pp. 173-182. Available at: https://www.iiste.org/Journals/index.php/EJBM/article/view/28340/29083.

Obeten, O. I., Ocheni, S., \& John, S. (2014)., 2(2) (2014) 'The Effects of Corporate Governance on The Performance of Commercial Banks In Nigeria.', International Journal of Public Administration and Management Research (LJPAMR), 2(2), pp. 219-234. Available at: https://www.iiste.org/Journals/index.php/EJBM/article/view/28340/29083.

Park, Y., Park, Y., Hong, P. C., \& Yang, S. (2017) 'Clarity of CSR Orientation and Firm Performance: Case of Japanese SMEs.', Benchmarking: An International Journal, 24(6), pp. 1581-1596. Available at: doi:https://doi.org/10.1108/BIJ-03-2016-0035.

Rehman, A., \& Shah, S. Z. (2013). (2013) 'Board Independence, Ownership Strusture and Firm Performance : Evidence From Pakistan.', Interdisciplinary Journal of Contemporary Research In Business, 5(3), pp. 832-845. Available at: https://journalarchieves34.webs.com/832-845.pdf.

Salami, K. (2011) 'Analysis of The Relationship Between Share Ownership Structure, Corporate Governance Structure, and Corporate Investment Efficiency, Using GSE Market Data (2005-2009)', Journal of Accounting and Finance, 11(4), pp. 111-118. Available at: http://t.www.na-businesspress.com/JAF/SalamiWeb11-4.pdf.

www.idx.co.id

Yilmaz , C., \& Buyuklu, A. H. (2016) 'Impacts Of Corporate Governance on Firm Performance: Turkey Case With A Panel Data Analysis', Eurasian Journal of Economics and Finance, 4(1), pp. 56-72. Available at: doi: 10.15604/ejef.2016.04.01.004 . 